were determined with high precision in the Fourier domain, we get the peak resolution

$$
R=\frac{2\left(t_{1}-t_{2}\right)}{\sigma_{1}+\sigma_{2}} .
$$

Fig. $1 A$ shows the $C_{7}$ and iso- $C_{8}$ gas chromatograms of the peaks obtained by using variable oven temperature. At $120 \mathrm{C}$ both peaks are practically overlapped, and the determination of the peak area is not possible. We get principally the same picture by using an analog to digital converter output $1 B$. Fig. $1 C$ shows the same peaks after the FFT. The plot contains 128 points. It shows that FFT sharpening may split an almost overlapped peak into two peaks, and this treatment enables to estimate the peak area ratio and retention time. At the same time the side band intensity increases and the overlapping of peaks decreases. The accuracy of the peak area which depends on the resolution is shown in Fig. 2. We can see that the FFT deconvolution gives more accurate results than the resolution using perpendicular drop (commonly used with integrators).

Taking into consideration that the

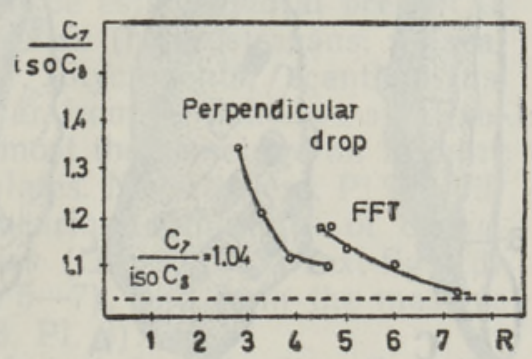

Fig. 2. The difference of peak areas ratio before and after FFT from the real weighed value.

FFT resolution compared with / other

methods gives more possibilities and determines more accurately the peak retention time and areas, the FFT data handling in gas chromatography is very helpful.

\title{
REFERENCES
}

1. Horlick G., Anal. Chem., 44, 943 (1972).

2. Kirmse W. D., Westerberg A. W., Anal. Chem., 43, 1035 (1971).

3. Fr a ser R. D. B., S uz u ki E., Anal. Chem., 38, 1770 (1966). Academy of Sciences of the Estonian SSR,
Institute of Chemistry
Received

Feb. 13, 1975

\author{
EESTI NSV TEADUSTE AKADEEMIA TOIMETISED, 24, KOIDE \\ KEEMIA * GEOLOOGIA. 1975, NR. 4 \\ ИЗВЕСТИЯ АКАДЕМИИ НАУК ЭСТОНСКОИ ССР. ТОМ 24 \\ ХИМИЯ * ГЕОЛОГИЯ. 1975, № 4
}

удК $567: 551.734(571.586)$

Elga MARK-KURIK

\section{A TOOTH-PLATE FROM THE LOWER DEVONIAN OF KOTELNY ISLAND}

ElRa MARK-KURIK. HAMBAPLAAT KOTELNOI SAARE ALAMDEVONIST

ЭЛЬこ М МАК-КУРИК. ЗУБНАЯ ПЛАСТИНКА ИЗ НИЖНЕГО ДЕВОНА ОСТРОВА КОТЕЛЬНОГО

Among the Early Devonian vertebrate remains collected in the Sokolova locality, Kotelny Island, New Siberian Archipelago (see Mark-Kurik, 1974), a peculiar small tooth-plate is of much interest. It has been found 
in the dark-grey limestone of the marine Pshenitsyn Formation of the Gedinnian-Siegenian age (sеe Черкесова, 1974). The specimen is included under the No. Pi 999 in the collection at the Geological Museum of the Academy of Sciences of the Estonian SSR.
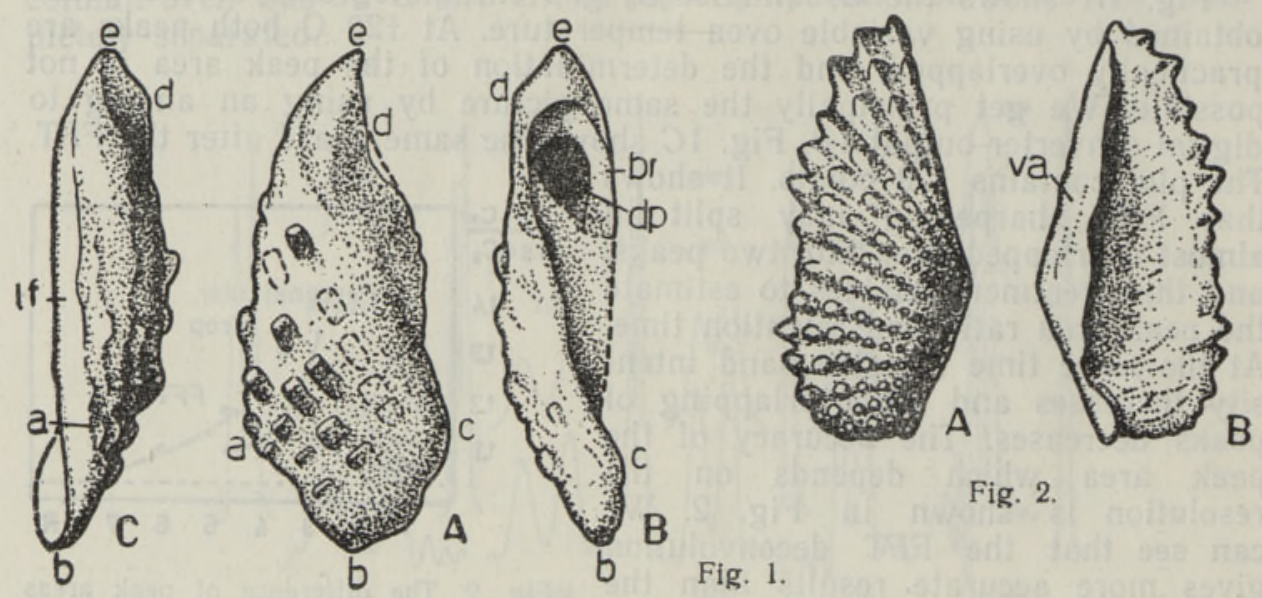

Fig. 2.

Text-fig. 1. A lower right tooth-plate $\mathrm{Pi} 999, \times 6.5$. Sokolova, Kotelny Island; Early Devonian, Gedimnian-Siegenian, Pshenitsyn Formation. A - dorsal, B - labial, $C$ - lingual view (all views made perpendicuharly to each other); $b r-b r i m, d p-$ depression, $l f$ - lingual facet.

Text-fig. 2. Lower left tooth-plate of Dipterus serratus (Eichw.), $\mathrm{Pi} 1000, \times 6.5$. At $166 \mathrm{~m}$ of Raigla boring core, Estonia; Middle Devonian, Eifelian, Narva Formation. $A$ - dorsal, $B$ - ventral view; $v a$ - ventral smooth area.

Of various tooth-plates known in fossil fishes, the specimen Pi 999 reveals some similarities to the tooth-plates of lungfishes, on one hand, and to those of bradyodont holocephalians, on the other. When compared with those plates, the specimen can be identified as a lower (mandibular) tooth-plate from the right jaw ramus. The tooth-plate Pi 999 (Text-fig. 1) is asymmetrical, elongated (the maximum length being $8 \mathrm{~mm}$ ) and twisted along its longitudinal axis. It bears a number of widely spaced blunt-topped pin-like teeth, the largest ones being $0.6-0.8 \mathrm{~mm}$ long. For comparison, a dipnoan tooth-plate of almost the same size, $6.5 \mathrm{~mm}$ long, can be presented (Pi 1000, Text-fig. 2). This fan-shaped plate, belonging to Dipterus serratus (Eichw.), is slightly vaulted and covered with numerous teeth of variable size and abutting bases, placed in radial rows, 15 in number. In specimen Pi 999 the well-separated teeth are situated on the dorsal and lingual surfaces of the plate (Text-fig. $1 A, C$ ) and seem to form 4 longitudinal rows. The first row at the anterior end of the posterior medial edge (Text-fig. $1, a-b$ ) consists of two small teeth. The other rows contain 6 teeth, at most (some of them have suffered). The ventrally placed lingual facet (Text-fig. $1 C, l f$ ) lacks teeth, and so is the case with the labial (lateral) surface. The latter cannot be observed in its full length, as the ventrolateral and ventral surfaces of the plate are covered with rock. The labial surface has a deep depression (Text-fig. $1 B, d p$ ) surrounded by a smooth brim $(b r)$. The concave lateral and ventral surfaces were apparently attached to Meckel's cartilage. As to the lingual facet, it may be analogous to the smooth marginal area on the ventral surface of the tooth-plate of Dipterus (Text-fig. $2 B, v a$ ). The position of 
this area relative to the jaw ramus in Dipterus is shown by E. Jarvik (1967, Text-fig. $6 A, M d T)$.

Taking into account its twisted shape, the specimen Pi 999 seems to be rather similar to the tooth-plate of bradyodont Cochtiodus (see Patterson, 1968, Text-fig. 12). However, the latter lacks teeth, and its smooth oral surface is separated by grooves into a number of transversal areas. Another bradyodont, Menaspis, has smooth tooth-plates: with these, Pi 999 agrees in general shape (see Bendix-Almgren, 1971, Text-fig. 5B).

As there is only a single specimen of the tooth-plate under consideration, its microstructure cannot be studied. Because of that and for morphological peculiarities as well, it cannot be established at present to which form the plate belongs. Of all vertebrates (heterostracans, palaeacanthaspids, arctolepids?, coccosteomorphs?, ptyctodonts, acanthodians, crossopterygians, paleoniscoids) known so far from the Sokolova and Rybnaya localities, i.e. from two localities of almost the same age on Kotelny Island, only ptyctodonts have paired tooth-plates. Nevertheless, Pi 999 differs markedly from the slender and erected shearing tooth-plates of Ctenurella (Ørvig, 1960, Text-fig. 4B), Rhynchodus (Gross, 1933, Text-fig. 16) and Rhamphodopsis (Miles, 1967, Text-fig. 5-7), and from the massive crushing tritors of Ptyctodus (Pander, 1858, P1. 8).

When some more material is available for study, showing that the tooth-plate Pi 999, and other plates of the same kind, belong to an Early Devonian ptyctodont, new interesting aspects of the affinities of such groups as ptyctodontid arthrodires, holocephalians and dipnoans, will be obtained.

\section{REFERENCES}

Bendix-A $1 \mathrm{mgren} \mathrm{S.} \mathrm{E.} \mathrm{1971.} \mathrm{The} \mathrm{anatomv} \mathrm{of} \mathrm{Menaspis} \mathrm{armata} \mathrm{and} \mathrm{the} \mathrm{phyletic}$ affinities of the menaspid bradyodonts. Lethaia, $4,21-49$.

Gross W. 1933. Die Wirbeltiere des rheinischen Devons. Abh. Preuss. Geol. Landesanst, N. F. H. $154,1-83$.

Jarvik E. 1967. On the structure of the lower jaw in dipnoans: with a description of an early Devonian dipnoan from Canada, Melanognathus canadensis gen. et sp. nov. J. Linnean Soc. (Zool.), 47, 311, 155-183.

Mark-KurikE. 1974. Discovery of new Devonian fish localities in the Soviet Arctic ENSV TA Toimet., Keem. Geol., Nr. 4, 332-335.

Miles R. 1967. Observations on the ptyctodont fish, Rhamphodopsis Watson. J. Linnean Soc. (Zool.), 47, 311, 99-120.

Ørvig T. 1960. New finds of Acanthodians, Arthrodires, Crossopterygians, Ganoids and Dipnoans in the Upper Middle Devonian Calcareous Flags (Oberer Plattenkalk) of the Bergisch Gladbach-Paffrath Trough. Pt. 1. Paläontol. Z., 34. 295-335.

P a nder C. 1858. Uber die Ctenodipterinen des devonischen Systems. St. Petersburg, $72 \mathrm{~S}$.

P atters on C. 1968. Menaspis and the bradyodonts. In: Ørvig T. (ed.). Current problems of lower vertebrate phylogeny. Stockholm, Almqvist \& Wiksell/Gebers Förlag AB, 171-205.

Черкесов а С. В. 1974. Некоторые вопросы стратиграфии нижне-среднедевонских отложений Таймыро-Колымской провинции. Тр. Сев.-Вост. компл. ин-та, 112-116.

Academy of Sciences of the Estonian SSR, Institute of Geology

Received June, 3, 1975 